\title{
EchoGéo
}

$51 \mid 2020$

Territoires « cyclonés »

\section{"Hurricaned" territories. Hurricane hazards and their impacts}

Introduction

Freddy Vinet and Frédéric Leone

\section{CpenEdition}

Journals

Electronic version

URL: https://journals.openedition.org/echogeo/20755

DOI: 10.4000/echogeo.20755

ISSN: 1963-1197

Publisher

Pôle de recherche pour l'organisation et la diffusion de l'information géographique (CNRS UMR 8586)

Electronic reference

Freddy Vinet and Frédéric Leone, "'Hurricaned" territories. Hurricane hazards and their impacts",

EchoGéo [Online], 51 | 2020, Online since 14 October 2020, connection on 10 August 2021. URL: http:// journals.openedition.org/echogeo/20755 ; DOI: https://doi.org/10.4000/echogeo.20755

This text was automatically generated on 10 August 2021.

EchoGéo est mis à disposition selon les termes de la licence Creative Commons Attribution - Pas d'Utilisation Commerciale - Pas de Modification 4.0 International (CC BY-NC-ND) 


\title{
"Hurricaned" territories. Hurricane hazards and their impacts
}

\author{
Introduction
}

\author{
Freddy Vinet and Frédéric Leone
}

1 This issue of EchoGéo investigates the environmental, social, economic and political consequences of hurricanes on territories and their management. The French neologism "cycloné" (or "hurricaned") appeared on social networks in 2017 after hurricane Irma hit the West Indies. The word refers to the destruction caused by category 4 or 5 hurricanes, but also to their victims' challenging experiences. These events raise the question of the ex-ante and ex-post evaluation of damages in terms of management: forecasting, preparation, crisis management and reconstruction, all from the perspective of impact mitigation. The spatial and multidimensional analysis of these events contributes to the development of a global geography of hazards and disasters, leading to the development of a flourishing field in French universities over the past two decades. Once again, this demonstrates our discipline's capacity of analysis, adaptation and response, in the context of current socio-environmental issues and the hazards they pose to our societies and territories.

The last few years saw particularly powerful hurricanes such as the Haiyan typhoon in the Philippines (2013), which was said to break records for low-pressure systems, or Irma and Maria in the West Indies, two consecutive category 5 hurricanes that struck just ten days apart in September 2017. Since 1851, observation centres have recorded 381 major tropical hurricanes reaching category 4 or above on the Saffir-Simpson scale (source IBTrACS/NOAA, 2020), mostly in the North Atlantic and North-West Pacific (Illustration 1). In terms of human casualties, 450,000 people have lost their lives since 1975 (1,419 deadly hurricanes), with particularly tragic events in India in 1977, Bangladesh in 1985 and 1991, Honduras in 1998, Myanmar in 2008, etc. (source EMDAT/ CRED, 2020). Such heavy casualties are not only observed in poor countries, as shown by the 1,833 victims made by Hurricane Katrina in the South of the USA in 2005 (Knabb et al., 2007). These low-pressure storms and the hazards they induce (floods, landslides, marine submersion) have caused considerable economic losses, estimated at US\$2,128 
billion worldwide since 1980 (source NatCat Service/Munich RE, 2020). In addition, non-financial impacts include environmental effects, particularly on coastal ecosystems and morpho-systems (Wang and Horwitz, 2007; Zhang et al., 2012), as well as health and social consequences (Rappaport, 2014). The spatial concentration of hazards in coastal areas is a source of concern for insurers and reinsurers, who are seeing an increase in the cost of claims. The devastation of small island complexes (habitats, infrastructure and tourist facilities destroyed, communications cut off, etc.) highlights the very causes of these territories' vulnerability: geographical isolation, small size, economic disparities, socio-spatial segregation, high exposure of the coastline, lack of local resources, governance problems, etc. The passage of Hurricane Irma in the Caribbean in September 2017 provided a clear demonstration of these issues.

Illustration 1 - Cyclonic activity and its human impacts. Territories studied in this issue

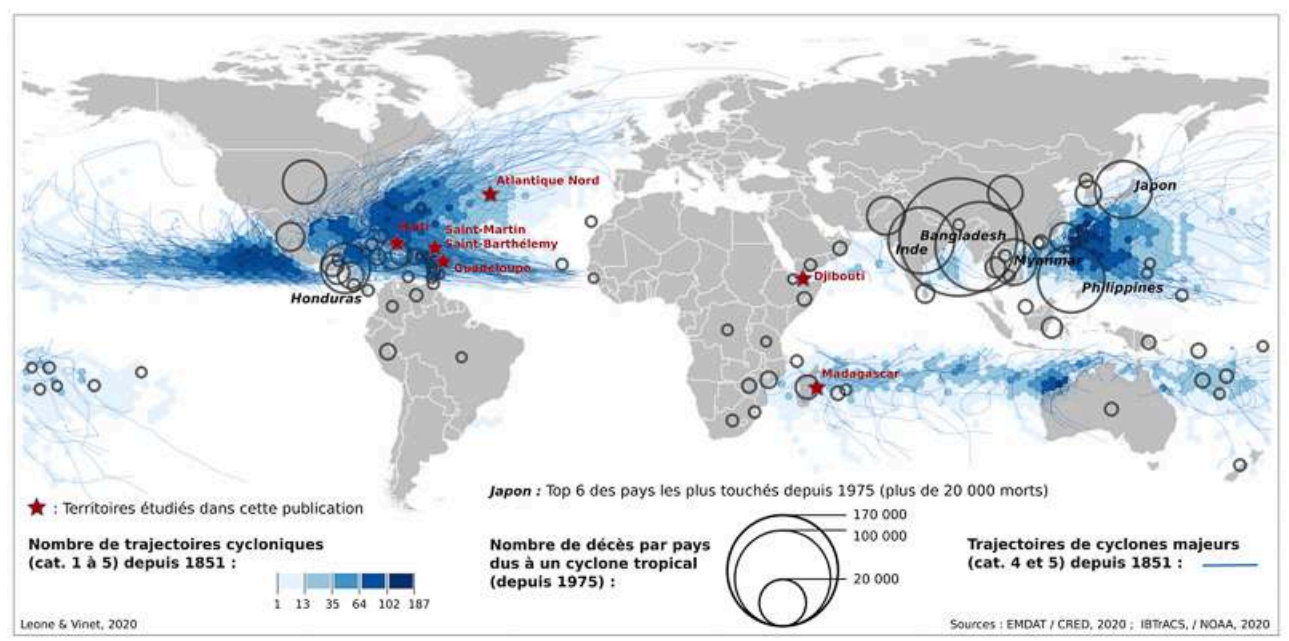

According to IPCC forecasts, cyclones will not be more numerous but more powerful in future years, even if the recent past does not always corroborate this trend, particularly in the western Pacific (Hoarau et al., 2018). There is also the question of the expansion in latitude of the area affected by these phenomena (Pilon et al., 2017). Quantification and a priori/a posteriori modelling methods are developing considerably, in particular through the use of satellite and light airborne imagery (FernandezGalarreta et al., 2015). How can the damage of a potential hurricane be predicted? Can it be categorized, quantified and mapped ex ante? After a hurricane event, tools for quantifying economic impacts provide almost real-time decision-making assistance that can be valuable for decision-makers and local managers. The recovery of cycloneaffected areas involves meeting and anticipating multiple challenges: re-housing of victims, restoration of public networks and services (education), waste management, diverse types of pollution, health risks. Their management can be improved through prior planning (business continuity plans) and capacity building for exposed societies (Gaillard et al., 2010). In terms of crisis management, how can events best be anticipated? Adapting institutional responses to local specificities is a key point in crisis management, with issues such as the preventive evacuation of affected areas, or communication malfunctions (between crisis managers, between authorities and the public...). How are past experiences taken on board in hurricane crisis management? Is experience capitalised or, as each case is different, does crisis management always involve a large share of improvisation? 
Beyond immediate feedback, these intense phenomena must be interpreted in light of their long-term consequences on territories. Do these events form ruptures or bifurcations in these territories' trajectories? What issues do they highlight as to their long-term development models? Decision-makers and scientists need feedback on the long term, on the impacts but also on the reconstruction phases (Moatty et al., 2017). Has the recovery been effective in terms of prevention and economic mechanisms, and ethical in terms of social justice? What physical and societal changes were brought about by the hurricane? Has it improved risk awareness and prevention? The reconstruction phase is crucial (Ingram et al. 2006). In theory, it provides a "window of opportunity" (Christoplos, 2006) to develop territorial resilience in preparation for future events, but it also reveals striking discrepancies between territories that have been lastingly impacted (Kelman, 2014) and others that can recover quickly. The fast recovery of the Vanuatu archipelago (Western Pacific) after Hurricane Pam in 2015 showed the resilience of traditional societies, despite their high exposure (Rey et al., 2017; Le Dé et al., 2018). Finally, to understand cyclone/territory relations, one must put these disasters into perspective within the territories' overall vulnerability trajectory (Duvat et al., 2017; Desarthe and Moncoulon, 2017).

5 This issue of EchoGéo sheds light on several of these aspects by favouring a geographical approach. It brings together thirteen contributions, covering seven cyclone-affected territories, from the Lesser North Antilles (Saint-Martin, Saint-Barthélemy) and the North Atlantic, through Guadeloupe and Haiti, to Djibouti and Madagascar in the Indian Ocean (Illustration 1). Seven of these articles focus in particular on the 2017 hurricane season, which was particularly trying for the French West Indies.

6 A first series of four articles addresses the issue of impacts, the central theme of this issue. Thibault Catry, Christophe Révillion, Pascal Mouquet, and Gwenaëlle Pennober show the contribution of satellite imagery for monitoring the impact of cyclonic events in Madagascar, examining the complementarity of scales and sensors and taking two cyclones as case studies (Haruna in 2013 and Enawo in 2017). Tony Rey, Thomas Candela, Matthieu Péroche and Frédéric Leone favour a field approach, using UAV imagery to assess coastal changes and flooding following the passage of Hurricane Irma on 5 and 6 September 2017 on the islands of Saint-Martin and Saint-Barthélemy. JeanPhilippe Cherel, Mustapha Nour Ayeh, Bouh Omar Ali and Freddy Vinet analyse a singular event (Cyclone Sagar) that occurred in May 2018 in the Gulf of Aden, and its socio-economic consequences on the city of Djibouti which is particularly not accustomed to this kind of event. Frederick Leone, Samuel Battut, Victoria Bigot, Guilhem Cousin Thorez, Thomas Candela and Freddy Vinet lay the methodological foundations for a historical catalogue of significant and deadly hydro-meteorological events that have struck the archipelago of Guadeloupe and the Northern Islands since 1635 , thus providing the opportunity to understand the main factors of human vulnerability to cyclones and their evolution over time.

7 Two articles address the hurricane crisis and its management, from an institutional or individual point of view. Valérie November, Alice Azémar, Sophie Lecacheux and Thierry Winter analyse obstacles to "good" crisis management, highlighting the fragmentation of the anticipation/decision binary in practice, considering different levels of response. The authors examine two case studies during the Irma-José-Maria crisis of 2017 in the West Indies: one is observed at the cross-ministerial level, and the other is experienced through a state operator on a territorial scale. Stéphanie Defossez 
and Monique Gherardi study the same event but focusing on the role played by the population in the management of the crisis in Saint-Martin, based on follow-up interviews conducted at different stages after the cyclone.

The next three contributions review the post-crisis issues of recovery and reconstruction of "hurricaned" territories. Annabelle Moatty, Delphine Grancher, Clément Virmoux and Julien Cavero address the issue of recovery after Hurricane Irma in Saint-Martin through the experiences and perceptions of teenagers, considering their accounts as data that could be fed into post-disaster feedback. For the same event and in Saint-Martin, Marie Cherchelay shows the reconstruction process through the prism of tourism, in order to analyse the complex interactions that develop around the issues and expectations that emerge in the post-crisis period. Simon Veitl questions the role of international aid in the reconstruction of Haiti, considering the case of schools in the Southern Department, after Hurricane Matthew in 2016.

9 A final series of four articles raises the question of evolutions and adaptations in the face of long-term hurricane hazards. Historian Jérémy Desarthe looks back on the major hurricane of September 1928 in Guadeloupe and its consequences, which he retraces until 1934 through administrative archives. Karl Hoarau, Florence Pirard and Ludovic Chalonge analyse the influence of current global warming on extreme hurricane activity in the North Atlantic (1945-2018), whose intensity and frequency are estimated thanks to aerial reconnaissance and to Dvorak's technique based on the reinterpretation of satellite images. The question of the long-term evolution of "hurricaned" societies is then addressed by Fanny Benitez, Magali Reghezza-Zitt and Nancy Meschinet de Richemond, who question the use of the notion of "risk culture" by the various players in the field of natural disaster prevention and crisis management in Guadeloupe, particularly in light of the 2017 hurricane season. Finally, Michel Desse, Monique Gherardi and Simon Charrier show how hurricanes cause positive or negative disruptions for island societies and economies in Guadeloupe, which are highly dependent on their coastlines and on the tourist activities they host.

\section{BIBLIOGRAPHY}

Blaikie P., Cannon T., Davis I., Wisner B., 1994. At risk: natural hazards, people's vulnerability, and disasters. Londres, Ed. Routledge.

Christoplos I., 2006. The elusive "window of opportunity" for risk reduction in post-disaster recovery, Intervention. ProVention Consortium Forum, Bangkok, 2-3 Février 2006, 4 p.

Desarthe J., Moncoulon D., 2017. Quatre siècles de cyclones tropicaux dans les départements d'outre-mer. La Météorologie, $\mathrm{n}^{\circ} 99$.

Duvat V., Magnan A., Russell M. et al., 2017. Trajectories of exposure and vulnerability of small islands to climate change. WIREs Clim Change [En ligne], e478. DOI: https://doi.org/10.1002/wcc. 478 
Fernandez-Galarreta J., Kerle N., Gerke M., 2015. UAV based urban structural damage assessment using object based image analysis and semantic reasoning. Nat. Hazards Earth Syst. Sci., vol. 15, p. 1087-1101.

Gaillard J.-C., Wisner B., Benouar D. et al., 2010. Alternatives pour une réduction durable des risques de catastrophe. Human Geography, vol. 3, n 1, p. 66-88.

Hoarau K., Chalonge L., Pirard F., Peyrusaubes D. 2018. Extreme tropical cyclone activities in the southern Pacific Ocean. International Journal of Climatology, vol. 38, p. 1409-1420.

Ingram J. C., Franco G., Rumbaitis-Del Rio, C., Khazai B., 2006. Post-disaster recovery dilemmas: challenges in balancing short-term and long-term needs for vulnerability reduction. Environmental Science \& Policy, vol. 9, p. 607-613.

Kelman I., 2014. Climate Change and Other Catastrophes: Lessons from Island Vulnerability and Resilience. Moving Worlds: a journal for transcultural writings, vol. 14, n 2, p. 127-140.

Knabb R. D., Rhome J. R., Brown D. P., 2007. National Hurricane Center. Tropical cyclone report: Hurricane Katrina, August 23-30, 2005. Miami, National Oceanic and Atmospheric Administration, National Weather Service, National Hurricane Center. https://www.nhc.noaa.gov/data/tcr/ AL122005_Katrina.pdf consulté le 15 Avril 2020.

Le Dé L., Rey T., Leone F., David G., 2018. Sustainable livelihoods and efFectiveness of disaster responses: a case study of tropical cyclone Pam in Vanuatu, Naturals Hazards, vol. 91, $\mathrm{n}^{\circ} 3$, p. 1203-1221.

Moatty A., Gaillard J.C., Vinet F., 2017. Du désastre au développement : Les enjeux de la reconstruction post-catastrophe. Annales de géographie, vol. 714, n 2, p. 169-194.

Pilon R., Chauvin F., Belmadani A., Palany P., 2017. North Atantic tropical cyclones: Historical simulations and future changes with the new high-resolution Arpege AGCM. AGU Fall Meeting, paper A53C-2258. URL: https://agu.confex.com/agu/fm17/meetingapp.cgi/Paper/239137

Rappaport E., 2014. Fatalities in the United States from Atlantic Tropical Cyclones: New Data and Interpretation. Bull. Am. Met. Soc. [En ligne], may. DOI: https://doi.org/10.1175/BAMS-

D-12-00074.1

Rey T., Le Dé L., Leone F., David G., 2017. An integrative approach to understand vulnerability and resilience postdisaster: the 2015 cyclone PAM in urban Vanuatu as case study, Disaster Prevention Management: an International Journal [En ligne], vol. 26, n 3, p. 259-275. DOI: https://doi.org/ 10.1108/DPM-07-2016-0137

Wang P., Horwitz M. H., 2007. Erosional and depositional characteristics of regional overwash deposits caused by multiple hurricanes. Sedimentology [En ligne], vol. 54, p. 545-564. DOI : https:// doi.org/10.1111/j.1365-3091.2006.00848.x

Zhang K., Liu H., Li Y., Smith T.J., 2012. The role of mangroves in attenuating storm surges. Estuarine, Coastal and Shelf Science [En ligne], vol. 102-103, p. 11-23. DOI: https://doi.org/10.1016/ j.ecss.2012.02.021

INDEX

Subjects: Sur le Champ - Sur le Terrain 


\section{AUTHORS}

\section{FREDDY VINET}

Freddy Vinet is a Professor in Geography of Natural Hazards at Université Paul-Valéry Montpellier 3.

\section{FRÉDÉRIC LEONE}

Frédéric Léone is a Professor in Geography of Natural Hazards at Université Paul-Valéry Montpellier 3. 